\title{
Roles of Corticotropin-Releasing Factor, Neuropeptide $Y$ and Corticosterone in the Regulation of Food Intake In Xenopus laevis
}

\author{
E. J. Crespi, ${ }^{*}$ H. Vaudry† and R. J. Denver* \\ *Department of Molecular, Cellular, and Developmental Biology, University of Michigan, Ann Arbor, MI, USA. \\ †European Institute of Peptide Research, Cellular and Molecular Neuroendocrinology, IFRMP 23, University of Rouen, Mont St Aignan, France.
}

Key words: corticotropin-releasing factor, neuropeptide $Y$, corticosterone, feeding behaviour, amphibians.

\begin{abstract}
In mammals, hypothalamic control of food intake involves counterregulation of appetite by anorexigenic peptides such as corticotropin-releasing factor (CRF), and orexigenic peptides such as neuropeptide $Y$ (NPY). Glucocorticoids also stimulate food intake by inhibiting CRF while facilitating NPY actions. To gain a better understanding of the diversity and evolution of neuroendocrine feeding controls in vertebrates, we analysed the effects of CRF, NPY and glucocorticoids on food intake in juvenile Xenopus laevis. We also analysed brain CRF and NPY mRNA content and plasma corticosterone concentrations in relation to nutritional state. Intracerebroventricular (i.c.v.) injection of ovine CRF suppressed food intake while CRF receptor antagonist $\alpha$ helical CRF(9-41) significantly increased food intake relative to uninjected and placebo controls. By contrast, i.c.v. injection of frog NPY and short-term corticosterone treatment increased food intake. Semi-quantitative reverse transcription-polymerase chain reaction analyses showed that CRF and NPY mRNA fluctuated with food intake in the brain region containing the mid-posterior hypothalamus, pretectum, and optic tectum: CRF mRNA decreased $6 \mathrm{~h}$ after a meal and remained low through 31 days of food deprivation; NPY mRNA content also decreased $6 \mathrm{~h}$ after a meal, but increased to prefeeding levels by $24 \mathrm{~h}$. Plasma corticosterone concentration increased $6 \mathrm{~h}$ after a meal, returned to prefeeding levels by $24 \mathrm{~h}$, and did not change with prolonged food deprivation. This postprandial increase in plasma corticosterone may be related to the subsequent increase in plasma glucose and body water content that occurs $24 \mathrm{~h}$ postfeeding. Overall, our data support the conclusion that, similar to other vertebrates, CRF is anorexigenic while NPY is orexigenic in $X$. laevis, and CRF secretion modulates food intake in the absence of stress by exerting an inhibitory tone on appetite. Furthermore, the stress axis is activated in response to food intake, but in contrast to mammals and birds is not activated during periods of food deprivation.
\end{abstract}

Corticotropin-releasing factor (CRF) and glucocorticoids are integral components of the hypothalamic-pituitary-adrenal (HPA) axis, or stress axis, and are known to be important factors in the central regulation of food intake and energy balance (1). Exogenous CRF causes anorexia in all classes of vertebrates tested to date (2), while short-term corticosterone treatment stimulates appetite in many studies $(3,4)$, although chronic corticosterone treatment may reduce food intake (5). The opposing actions of $\mathrm{CRF}$ and corticosterone are hypothesized to be a part of the adaptive physiological response to an acute environmental stressor (6). The initial hypothalamic CRF secretion associated with the 'fight or flight' response inhibits foraging and promotes survival behaviours. The appetite-stimulating effects of increased plasma corticosterone concentration occur after the stressful stimuli ceases, and CRF secretion is reduced, to restore energy reserves to homeostatic levels (6).

In addition to their effects on appetite in stressful situations, there is evidence suggesting that CRF and corticosterone are also involved in the regulation of energy balance in the absence of stress. From studies primarily conducted on rodents, the model of hypothalamic control of appetite involves the counterregulation of appetite-suppressing neuropeptides (anorexigenic), such as CRF, and appetite-stimulating neuropeptides (orexigenic), such as neuropeptide Y (NPY) (7). There is evidence that basal CRF secretion regulates food intake because mice overexpressing CRF binding protein (CRF-BP), which sequesters CRF in the rodent brain, exhibit increased food intake and body weight (8). Conversely, CRF-BP deficient mice reduce food intake and lose weight. Basal

Correspondence to: Dr Erica J. Crespi, Department of Molecular, Cellular, and Developmental Biology, University of Michigan, Ann Arbor, MI 48109-1048, USA (e-mail: ejcrespi@umich.edu). 
CRF secretion may exert a suppressive action on orexigenic neurones (e.g. NPY) because CRF is known to inhibit NPY synthesis (7). Circulating glucocorticoids stimulate food intake via two pathways. First, glucocorticoids are a permissive factor that facilitates the orexigenic effect of NPY because adrenalectomized rodents do not increase food intake when exogenous NPY treatments are applied (9). Second, glucocorticoids inhibit CRF neurones, thus reducing the anorexigenic effects of CRF (1).

The central distributions of CRF and NPY neurones have been mapped in the amphibian brain $(10,11)$, but little is known about their physiological actions in amphibians. The roles of CRF and corticosterone in development have been analysed in several amphibian species (12), although few studies have investigated the involvement of these hormones in the regulation of food intake. Central injections of CRF inhibit food intake and preycatching behaviour in two frog species $(2,13)$. Long-term treatment with corticosterone suppressed growth in Rana pipiens tadpoles (14); however, it is not known if the growth inhibition was caused by a reduction in food intake, an inhibition of growth independent of feeding, or a combination of both. The actions of NPY have been studied in the South African clawed frog, Xenopus laevis, in the context of background adaptation (15), but not in the context of food intake regulation. In these studies, NPY inhibited secretion of $\alpha$-melanocyte-stimulating hormone, an anorexigenic neuropeptide that also promotes skin darkening (15).

The present study focused on the roles of CRF, NPY and corticosterone in the regulation of food intake in the $X$. laevis. We experimentally addressed the following questions: (i) does exposure to exogenous CRF, NPY, or corticosterone affect food intake and (ii) does brain CRF or NPY mRNA content, or plasma corticosterone concentration vary with nutritional state? If CRF acts as an appetite suppressant in frogs, we predicted that exogenous CRF would suppress food intake, and that hypothalamic CRF mRNA expression would be negatively correlated with appetite. If NPY and corticosterone stimulate appetite in X. laevis, as they do in other vertebrates, then exogenous NPY and corticosterone should increase food intake. Furthermore, we predicted that brain NPY mRNA content and plasma corticosterone concentration would be positively correlated with appetite. We also measured plasma glucose, plasma insulin-like growth factor binding proteins (IGFBPs), and physical parameters (e.g. body and fat mass) as indicators of energy balance.

\section{Materials and methods}

Animal husbandry

All procedures were conducted in accordance with the guidelines established by the University Committee on Use and Care of Animals at the University of Michigan. Xenopus laevis juveniles were obtained from an in-house breeding stock originally derived from the population at Xenopus I (Dexter, MI, USA). For all experiments, frogs were maintained at $23{ }^{\circ} \mathrm{C}$ on a $12: 12 \mathrm{~h}$ light dark cycle (lights on at $07.00 \mathrm{~h}$ and off at $19.00 \mathrm{~h})$ in $4-1$ aquaria $(29 \times 19 \times 12.5 \mathrm{~cm})$.

\section{Hormones and reagents}

Ovine CRF (oCRF, Sigma-Aldrich, St Louis, MO, USA) and $\alpha$ helical-CRF(9-41) (Sigma) were used in experiments examining CRF effects on food intake in $X$. laevis. We chose to use ovine CRF rather than X. laevis $\mathrm{CRF}$ as the former binds to $X$. laevis CRF receptors with an affinity similar to the $X$. laevis CRF (16) but does not bind to the $X$. laevis CRF-BP (16). Thus, the use of oCRF should remove any confounding effects of binding to endogenous CRF-BP, which is expressed at a high concentration in the $X$. laevis brain (17). Corticosterone was obtained from ICN
Biomedicals (Aurora, OH, USA). Frog NPY was synthesized by solid phase methodology as previously described (18); the amino acid sequence of this peptide is identical to that of $X$. laevis NPY.

\section{Food intake assay}

Frogs were given introcerebroventricular (i.c.v.) injections of neuropeptides (described below) and, $1 \mathrm{~h}$ later, they were given a measured quantity of beef liver pieces (approximately $10 \mathrm{mg} /$ piece). After $10 \mathrm{~min}$, the food remaining was retrieved from the tank, blotted of excess water and weighed. Food intake was measured as the remaining mass of food $(\mathrm{mg})$ subtracted from the original food mass, divided by the body weight of the frog in grams ( $g$ b.w.). Analysis of variance (ANOVA) was used to determine if food intake varied among treatment groups, and Duncan's multiple comparisons tests were used to determine within-treatment differences in food intake.

Plasma corticosterone radioimmunoassay (RIA)

Corticosterone was analysed in plasma by RIA following ether extraction (100 $\mu \mathrm{l}$ plasma per sample). To estimate recoveries, $\left[{ }^{3} \mathrm{H}\right]$-corticosterone (3500 c.p.m.) was added to each plasma sample and incubated at room temperature for $30 \mathrm{~min}$ before extraction. Samples were resuspended in $500 \mu \mathrm{l}$ assay buffer (PBS-G: $0.02 \mathrm{M}$ sodium phosphate, $\mathrm{pH} 7.3,0.9 \% \mathrm{NaCl}, 0.1 \%$ gelatin) and analysed by RIA as described by Licht et al. (19). Anti-corticosterone serum was purchased from Endocrine Sciences (Calabasas, CA, USA), and $\left[{ }^{3} \mathrm{H}\right]$-corticosterone was purchased from Perkin-Elmer, Inc. (Boston, MA, USA).

All samples within an experiment were analysed within a single RIA, except for those in the Satiation/Food Deprivation Experiment (samples from each time collection were represented in each of the five assays). Two samples of pooled extracted normal rabbit serum were included in each assay as quality control standards. The interassay coefficient of variation was $16 \%$. Plasma samples exhibited parallelism in the RIA. ANOVA was used to measure time differences in plasma corticosterone concentrations.

Effects of CRF on food intake

\section{Experiment 1}

The purpose of this experiment was to determine if CRF exerts a dose-dependent inhibitory effect on food intake. All juvenile $X$. laevis (0.6-1.5 g b.w.) were fed once every other day at $12.00 \mathrm{~h}$ for at least 10 days. Frogs were fasted for $48 \mathrm{~h}$ before injections to ensure that appetite would be high before the experiment. On the day of the experiment, frogs were anaesthetized by submersion in $0.005 \%$ benzocaine. We administered i.c.v. microinjections of saline (vehicle control) or oCRF $(n=5-6)$ at the following doses ( $\mathrm{n}$ b.w.): 0.02, 0.20 and 2.0. A volume of 100-150 nl containing the appropriate dose of oCRF was pressure injected with a micropipette. Based on the microinjection procedure of Lowry and Moore (20), we first pierced a hole through the skull using a 26.5-gauge needle, then inserted the micropipette through the hole into the third ventricle using a Drummond Nanoject apparatus (Drummond Scientific Co, Bromwell, PA, USA). The precise position of the needle for delivery was determined in preliminary experiments by injection of $1 \%$ fast green dye; however, no dye was used in the CRF injection experiments. After injection, frogs were placed in tanks without anaesthetic for recovery. The frogs typically recovered within $20 \mathrm{~min}$ after injection, and food intake was assayed as described above.

\section{Experiment 2}

To test if the action of CRF was specifically mediated through CRF receptors and whether endogenous CRF secretion regulates food intake, we conducted an experiment using the CRF receptor antagonist, $\alpha$ helical CRF $(9-41)$, which binds to both CRF receptor types. We fed juveniles (1.0-2.0 g b.w.) approximately $20 \mathrm{mg}$ of beef liver each at $4 \mathrm{~h}$ before injection to ensure that appetite would be relatively low among experimental frogs, and conducted the same anaesthesia and i.c.v. injection procedures described in experiment 1 . The frogs $(n=7)$ were given i.c.v. injections of saline (vehicle control), $20 \mathrm{ng} / \mathrm{g}$ b.w. oCRF, $200 \mathrm{ng} / \mathrm{g}$ b.w. $\alpha$ helical CRF(9-41), or a combination of $20 \mathrm{ng} / \mathrm{g}$ b.w. oCRF and $200 \mathrm{ng} / \mathrm{g}$ b.w. $\alpha$ hel-CRF(941). We also included a noninjected ('unstressed') group in this experiment. Food intake was assayed as described above.

\section{Effects of NPY on food intake}

To determine the effect of NPY on food intake, we fed juveniles (0.6-1.3 g b.w.) approximately $20 \mathrm{mg}$ of beef liver each at $4 \mathrm{~h}$ before injection to ensure that appetite would be relatively low among experimental frogs. The anaesthesia and i.c.v. 
injection procedures were the same as described above. Frogs $(n=8)$ were given i.c.v. injections of saline (vehicle control), $10 \mathrm{ng} / \mathrm{g} \mathrm{b}$.w. frog NPY or $100 \mathrm{ng} / \mathrm{g}$ b.w. frog NPY. Food intake was assayed as described above.

\section{Effects of corticosterone on food intake}

To determine the effect of corticosterone on food intake, we treated frogs noninvasively with either corticosterone or a corticosterone synthesis blocker (metyrapone). On the first day of the experiment, frogs $(n=5$ per treatment) were fed liver pieces to satiation at $12.00 \mathrm{~h}$. After feeding, the frogs were placed in 21 of water to which ethanol vehicle $(0.0043 \%$ final concentration; control), corticosterone ( $2 \mathrm{mM}$ final concentration) or metyrapone $(0.11 \mu \mathrm{M}$ final concentration) were added. Metyrapone is a corticosterone synthesis inhibitor that has been used successfully in frogs $(14,21)$. In previous experiments, this concentration of metyrapone did not cause any obvious pathological behaviours in $X$. laevis juveniles or tadpoles. After $24 \mathrm{~h}$, frogs were submerged in $0.01 \%$ benzocaine, killed, and plasma was collected with heparinized capillary tubes from an incision in the truncus arteriosus for corticosterone RIA. In a separate experiment, we tested the effects of corticosterone or metyrapone on food intake by exposing juvenile frogs $(n=4$ per treatment) to hormone or drug treatments for $24 \mathrm{~h}$, then assaying food intake as described above.

\section{Satiation/food deprivation experiment}

The purpose of this experiment was to determine if brain CRF or NPY mRNA content or plasma corticosterone concentration vary with level of appetite and nutritional state. Juveniles (4.8-9.5 g b.w.) were housed individually in 4-1 containers and hand-fed approximately $100 \mathrm{mg}$ of liver pieces each at $12.00 \mathrm{~h}$ every other day for 10 days. After a $48 \mathrm{~h}$ fast, frogs were allowed to feed ad libitum until satiated. The frogs were randomly assigned to one of 11 collection groups $(n=6-7$ per group) such that there were no significant differences in mean body size among groups. To measure immediate responses to food intake, blood samples and brain sections were collected in a prefeeding sample $(-1 \mathrm{~h})$ and three postfeeding samples $(2,6$ and $24 \mathrm{~h})$. To measure changes in response to short-term food deprivation, blood samples and brain sections were collected at $12.00 \mathrm{~h}$ on $2-6$ days after the satiation meal. Finally, to measure changes in response to long-term food deprivation, blood samples and brain sections were collected at $12.00 \mathrm{~h}$ on days 14 and 31 after the satiation meal.

At each collection time, frogs were anaesthetized by submersion in $0.005 \%$ benzocaine and blood samples were collected into heparinized capillary tubes from an incision in the truncus arteriosus. Two brain sections were analysed for mRNA content. Section 1 included the olfactory lobes, telencephalon, anterior hypothalamus (preoptic area) and Section 2 included the mid-posterior hypothalamus, pretectum, optic tectum, and pituitary. Tissues were snap frozen on dry ice after dissection and stored at $-80^{\circ} \mathrm{C}$ until processed. Plasma was stored at $-20{ }^{\circ} \mathrm{C}$ until assayed for corticosterone.

In addition, wet body mass, stomach content mass, and abdominal lipid body mass were measured. Wet body mass was calculated by subtracting the masses of the stomach contents and abdominal fat bodies from the total wet mass of the frog. Frog carcasses (not including fat and stomach contents) were then dried in an oven at $55^{\circ} \mathrm{C}$ and weighed for lean body mass. Multivariate analysis of variance (MANOVA) was used to analyse physical body measurements, using time of sample as a main effect and original mass as a covariate.

\section{CRF and NPY mRNA measurement}

To assess changes in CRF and NPY mRNA content in the two brain regions, we used semiquantitative multiplex reverse transcription-polymerase chain reaction (RT-PCR) analysis. Total RNA was extracted from brain tissues with TRIzol (Life Technologies, Carlsbad, CA, USA) following the manufacturer's protocol, and RNA concentrations were quantified by spectrophotometry. Total RNA was reverse transcribed into cDNA according to the Clontech Laboratories, Inc. (Palo Alto, CA, USA) protocol for first strand cDNA synthesis using a poly dT primer. Each RT reaction included: $1 \mu \mathrm{g}$ total RNA, $5 \times$ first strand buffer, $0.1 \mathrm{M}$ DTT, $10 \mathrm{~mm}$ dNTPs and $1 \mu \mathrm{l}$ of Superscript II RNase $\mathrm{H}^{-}$reverse transcriptase (Invitrogen Inc., Groningen, the Netherlands). After $1.5 \mathrm{~h}$ of cDNA synthesis at $42{ }^{\circ} \mathrm{C}$, reactions were terminated by incubation at $71^{\circ} \mathrm{C}$ for $10 \mathrm{~min}$ then stored at $4{ }^{\circ} \mathrm{C}$.

We analysed the potential for genomic DNA contamination of our RNA samples by conducting PCR on one-third of the RT products using primers designed to amplify a region of genomic DNA $(1 \mathrm{~kb})$ upstream of the transcription start site of the $X$. laevis CRFa gene (22). As positive controls for the PCR, we used purified $X$. laevis genomic DNA or a plasmid containing the $X$. laevis CRFa gene (22). This analysis confirmed that genomic DNA was not present in any of our samples and thus the DNA fragments that we analysed were derived from cDNA.

For semiquantitative multiplex PCR, we used the X. laevis ribosomal protein L8 (rpL8) to control for differences in RNA loading, RNA quality and cDNA synthesis (23). We conducted two $25 \mu \mathrm{l}$ PCR reactions for each sample: one with primers for CRF and $\mathrm{rpL} 8$, and another with primers for NPY and $\mathrm{rpL8}$. Primer sequences were: CRF sense $5^{\prime}$ - to $3^{\prime}$-TCTCCTGCCTGCTCTGTCCAA, and antisense $5^{\prime}$ - to $3^{\prime}$ CTTGCCATTTCTAAGACTTCACGG; NPY sense $5^{\prime}$ - to $3^{\prime}$-GATGCAGGGAAACATGAGG and antisense $5^{\prime}-$ to $3^{\prime}$-CTCCACCAAACATCTGAAACG; rpL8 sense $5^{\prime}$ - to $3^{\prime}$-CACAGAAAGGGTGCTGCTAAG and antisense $5^{\prime}$ - to $3^{\prime}$-CAGGATGGGTTTGTCAATACG. The size of the PCR products for CRF, NPY and rpL8 were $321 \mathrm{bp}, 240 \mathrm{bp}$ and $477 \mathrm{bp}$, respectively. Before multiplex PCR analysis, a thermal gradient of annealing temperatures and a series of cycle numbers were tested for each brain section and primer set to determine optimal PCR conditions. Following procedures described by Pernas-Alonso et al. (24), primer concentrations were adjusted so that the linear ranges of amplification for each gene were coincident so that measurement of each gene could be made from a single reaction. The specifics for each primer set and brain section are reported below.

For CRF analysis, each reaction contained $1 \mu \mathrm{l}$ RT product, $0.3 \mu \mathrm{M}$ of each CRF primer, $0.08 \mu \mathrm{M}$ of each rpL8 primer, $1.5 \mathrm{mM} \mathrm{MgCl}_{2}$ and $1.25 \mathrm{U}$ HotStar Taq DNA polymerase (Qiagen Ltd, Crawley, UK). The PCR conditions were $15 \mathrm{~min}$ at $95{ }^{\circ} \mathrm{C}$, followed by 30 cycles (brain Section 1) or 28 cycles (brain Section 2) of $94^{\circ} \mathrm{C}$ for $45 \mathrm{~s}, 61^{\circ} \mathrm{C}$ for $45 \mathrm{~s}$, and $72{ }^{\circ} \mathrm{C}$ for $1 \mathrm{~min}$, and a final 10 -min extension at $72{ }^{\circ} \mathrm{C}$. For NPY analysis, each reaction contained $1 \mu \mathrm{RT}$ product, $0.2 \mu \mathrm{M}$ of each NPY primer, $0.1 \mu \mathrm{M}$ of each rpL8 primer, $1.5 \mathrm{mM} \mathrm{MgCl}_{2}$ and $1.25 \mathrm{U}$ Taq DNA polymerase (Buffer B, Promega Inc., Madison, WI, USA). The PCR conditions for analysis of both brain regions were $4 \mathrm{~min}$ at $94^{\circ} \mathrm{C}$, followed by 29 cycles of $94^{\circ} \mathrm{C}$ for $1 \mathrm{~min}$, $60{ }^{\circ} \mathrm{C}$ for $1 \mathrm{~min}$ and $72{ }^{\circ} \mathrm{C}$ for $2 \mathrm{~min}$, and a final $10 \mathrm{~min}$ of elongation at $72^{\circ} \mathrm{C}$.

PCR products were analysed on a $1.5 \%$ agarose gel. Ethidium bromide-stained bands were visualized by ultraviolet illumination and images were digitally recorded. The intensity of each band was quantified by densitometric analysis using Scion Image software (version 4.05 for Windows) (Scion Corp. Frederick, MD, USA). For each gene, densitometric values were first standardized by dividing by the group mean. CRF and NPY values were then normalized for differences in RNA loading by dividing by the corresponding rpL8 densitometric values. These ratios were square-root transformed and analysed with ANOVA. Data for both CRF brain sections were taken from two separate gels with samples from each treatment equally distributed among the gels; therefore, we conducted a two-factor ANOVA to account for gel and treatment differences in band intensity (i.e. neuropeptide content). The NPY data for each brain section were collected from a single gel. Accordingly, only the treatment effect was analysed in the ANOVA.

\section{Plasma glucose assay}

Plasma glucose was assayed using Sigma Diagnostics procedure no. 510, which was modified from Raabo and Tirkildsen (25). Five $\mu 1$ of plasma per frog was added to $95 \mu \mathrm{l}$ distilled deiodinized (dd) water and $1 \mathrm{ml}$ of glucose oxidase, peroxidase and odianisidine mixture. All samples were incubated at $37^{\circ} \mathrm{C}$ for $30 \mathrm{~min}$. Within $3 \mathrm{~min}$ after incubation, $250 \mu \mathrm{l}$ of each sample was analysed in a plate spectrophotometer (Titertek Multiscan Plus, ICN Biomedicals Inc., Huntsville, AL, USA) for light absorbency using a $450 \mathrm{~nm}$ filter. Serum glucose $(\mathrm{mg} / \mathrm{dl})$ was calculated by dividing the sample optical density reading by the standard reading, then multiplying by 100 . Analysis of variance was used to analyse plasma glucose concentration with time of sample as a main effect. Because glucose was measured in two runs, with replicates of each treatment in each run, we included run and treatment as main effects in the ANOVA.

\section{IGFBP Western ligand blot analysis}

We measured plasma concentrations of IGFBPs as an endocrine indicator of nutritional state. Currently, there are no homologous assays established for other indicators, such as insulin, glucagon, or IGF-1 in amphibians, but Western ligand blot analysis enabled us to analyse relative levels of plasma IGFBPs. Given that IGFBP-1 concentration is positively regulated by insulin and negatively regulated by glucagon in mammals $(26,27)$, and previous studies in mammals and fish have shown that elevations in plasma IGFBP-1 levels are associated with food deprivation $(28,29)$, we hypothesized that the $X$. laevis plasma IGFBP profile would reveal a similar pattern. We followed the methods of Hossenlopp et al. (30) with modifications. Plasma samples $(5 \mu \mathrm{l})$ were dissolved in SDS sample buffer (Tris base, $0.125 \mathrm{~mol} / 1$; $4 \%$ SDS; $20 \%$ glycerol, $0.1 \%$ bromophenol blue) and heated to $65{ }^{\circ} \mathrm{C}$ for $10 \mathrm{~min}$ before electrophoresis in a $10 \%$ polyacrylamide gel. A pool of rat plasma $(5 \mu \mathrm{l})$ was run on each gel to serve as a quality control standard because the rat blood IGFBP banding pattern is known. 
Proteins were transferred to nitrocellulose membranes (Bio-Rad, Hercules, CA, USA) and the membranes were blocked overnight in tris-buffered saline containing $1 \%$ bovine serum albumin (TBS-BSA). Blots were then rinsed and probed with $\left[{ }^{125} \mathrm{I}\right]$-labelled human IGF-I (iodinated by the chloramine $\mathrm{T}$ method) at 200000 c.p.m./ml TBS-BSA. Following autoradiography, images were digitized using a flatbed scanner and the resulting IGFBP bands were quantified using Scion Image software as described above. We considered band intensity, calculated in arbitrary densitometric units, to be a relative measure of plasma IGFBP levels. Analysis of variance was used to analyse band intensity from the ligand blots; because five blots were used to analyse all the samples, blot and time of collection were included as main effects in the ANOVA.

Measurement of daily fluctuations in plasma corticosterone and glucose concentration

To determine if plasma corticosterone and glucose concentrations fluctuated during the day without a meal, we measured plasma concentrations twice a day for 3 days. Frogs (4.0-8.0 g b.w.) were housed individually in 4-1 aquaria and entrained to a feeding cycle in which they were fed at $13.00 \mathrm{~h}$ every $48 \mathrm{~h}$ for 2 weeks. In continuance with the feeding regime, one meal was given at $13.00 \mathrm{~h}$ on the first day of collections, but frogs were fasted on subsequent days. Plasma samples $(\mathrm{n}=4-5)$ were collected at the following times: day 1: $12.00 \mathrm{~h}$ (prefeeding) and $18.00 \mathrm{~h}$ ( $5 \mathrm{~h}$ postfeeding); day $2: 12.00 \mathrm{~h}$ and $18.00 \mathrm{~h}$; day $312.00 \mathrm{~h}$ and $18.00 \mathrm{~h}$. Plasma corticosterone was measured by RIA, and plasma glucose was measured by enzymatic assay (see above).

\section{Results}

\section{CRF effects on food intake}

Injections of oCRF into the third ventricle reduced food intake in a dose-dependent manner relative to vehicle-injected controls [ANOVA: $\mathrm{F}(3,18)=3.89, \mathrm{P}=0.026$ ] (Fig. 1A). Blockade of CRF receptors by injection of $\alpha$ helical $\mathrm{CRF}(9-41)$ significantly increased food intake compared with uninjected and salineinjected groups [ANOVA: $\mathrm{F}(4,30)=5.86, \mathrm{P}<0.001$ ] (Fig. 1B). Food intake in frogs coinjected with CRF plus ahelical CRF(9-41) did not differ from either control group [i.e. $\alpha$ helical CRF(9-41) blocked the anorectic effect of CRF].

\section{NPY effects on food intake}

Injections of either $20 \mathrm{ng} / \mathrm{g}$ or $200 \mathrm{ng} / \mathrm{g}$ frog NPY significantly increased food intake in $X$. laevis juveniles relative to controls [ANOVA: $\mathrm{F}(2,21)=3.47, \mathrm{P}=0.008$ ] (Fig. 1C).

\section{Corticosterone effects on food intake}

Treatment with corticosterone $(2 \mathrm{mM})$ for $24 \mathrm{~h}$ caused an approximate three-fold increase in plasma corticosterone concentration above controls (Fig. 2A). This treatment also increased food intake relative to vehicle-treated controls (Fig. 2B). By contrast, metyrapone reduced plasma corticosterone concentration to nondetectable levels [ANOVA: $\mathrm{F}(2,11)=8.74 ; \mathrm{P}=0.005$ ], but did not alter food intake [ANOVA: $\mathrm{F}(2,9)=17.34 ; \mathrm{P}=0.0008$ ].

\section{Satiation/food deprivation experiment}

\section{Physical measurements}

Stomach contents increased by approximately $17 \%$ of total body mass after the meal but, by $6 \mathrm{~h}$, approximately half the food had cleared the stomach (Table 1). Almost all food cleared the stomach by 2 days after the meal. Neither wet nor dry body mass significantly changed with collection time, but body water content
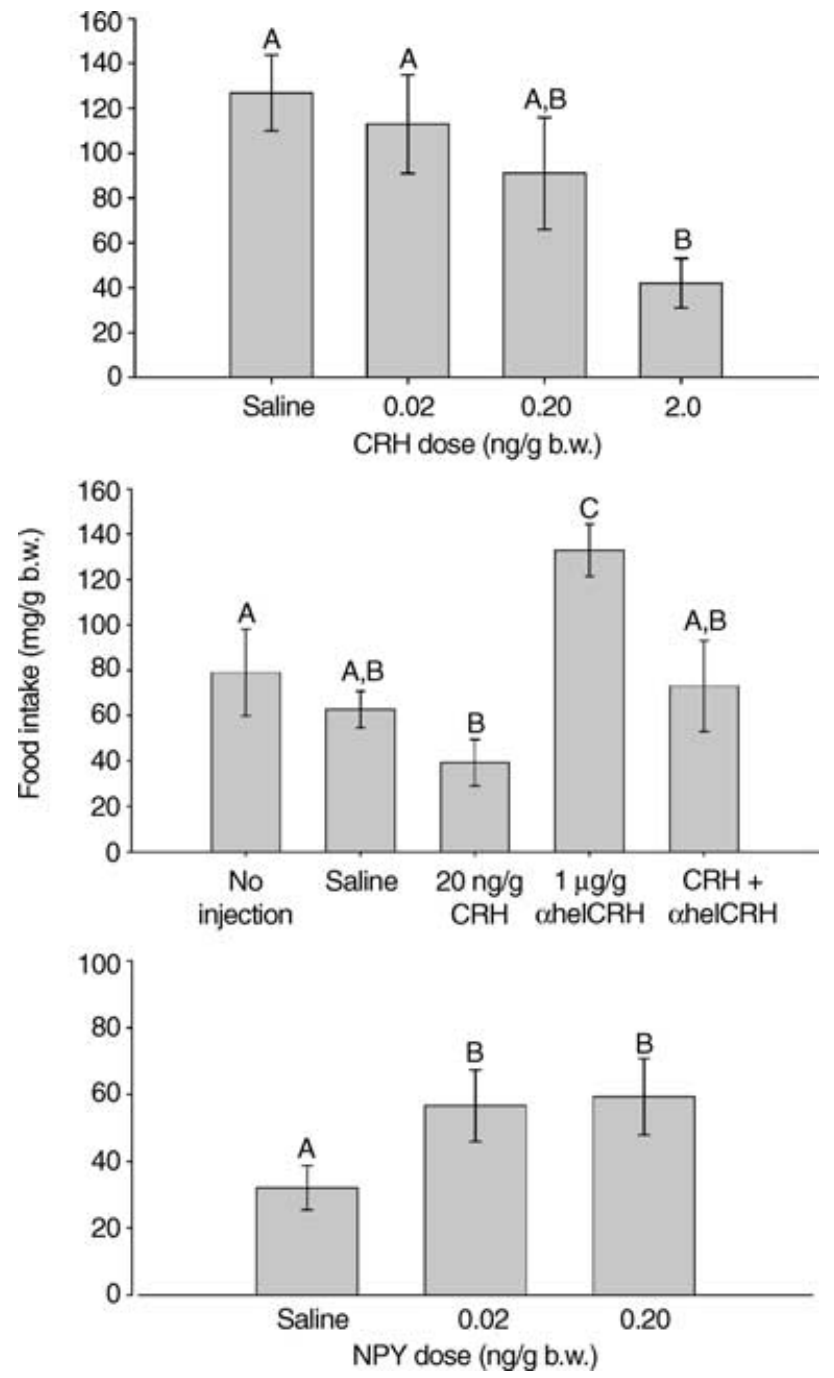

FIG. 1. Effects of corticotropin-releasing factor (CRF) on food intake in Xenopus laevis juveniles. (A) Mean \pm SEM of food intake after i.c.v. injections of varying doses of ovine CRF (oCRF) $(n=5-6)$. (B) Mean \pm SEM of food intake after i.c.v. injections of oCRF, $\alpha$ helical CRF, and coinjection of oCRF and $\alpha$ helical CRF compared to handling (no injection) and placebo (saline) controls $(n=7)$. (C) Mean \pm SEM of food intake after i.c.v. injections of varying doses of frog neuropeptide Y (NPY) $(n=8)$. In all graphs, doses are given in ng per gram body weight (ng/g b.w.) of the frog, and letters indicate statistically significant groupings as determined by Duncan's multiple comparison tests $(\mathrm{P}<0.05)$.

significantly increased 1 day after feeding relative to the prefeeding sample (Table 1). The wet mass of fat bodies was significantly lower than prefeeding fat mass on days 5 and 31 of food deprivation (Table 1).

\section{CRF and NPY content analysis}

Semi-quantitative RT-PCR analyses revealed that both CRF and NPY mRNA expression varied with nutritional state in the forebrain/anterior hypothalamic region (Section 1) and the midbrain/ mid-posterior hypothalamic region (Section 2) (Fig. 3A). Analysis of variance also confirmed that the mRNA levels of the housekeeping gene, rpL8, did not vary among treatments in any of the analyses (unpublished data). CRF mRNA expression in Section 1, 

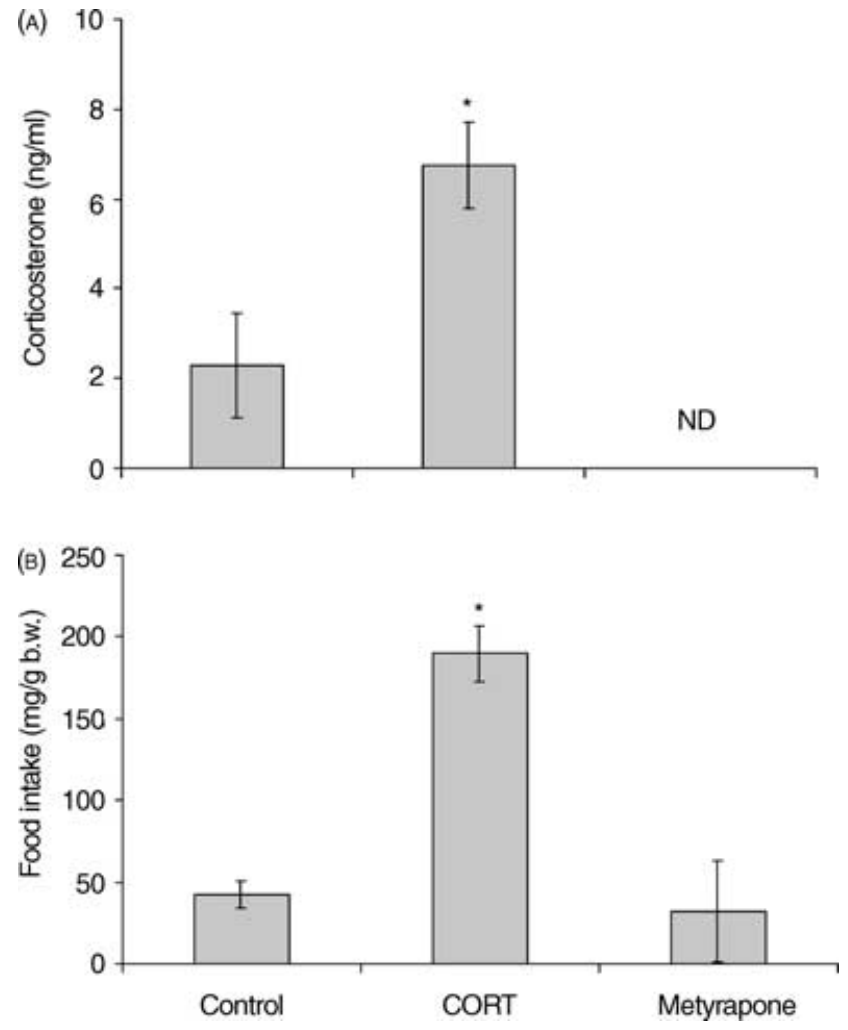

FIG. 2. Effects of $24 \mathrm{~h}$ of exposure to aquarium water treated with corticosterone $(2 \mathrm{mM}, \mathrm{CORT})$ or corticosterone synthesis inhibitor metyrapone $(0.11 \mu \mathrm{M})$ on (A) plasma corticosterone concentration and (B) food intake in Xenopus laevis juveniles. Controls were exposed to aquarium water treated only with vehicle (ethanol at $0.0043 \%$ ). * Significant differences between treatment mean and control $(\mathrm{P}<0.05)$.

Table 1. Changes in Physical Measurements in Xenopus laevis Juveniles $(\mathrm{n}=5-7)$ Experiencing Different Periods of Food Deprivation.

\begin{tabular}{lclll}
\hline Time & $\begin{array}{l}\text { Stomach } \\
\text { contents }(\mathrm{mg})\end{array}$ & $\begin{array}{l}\text { Body dry } \\
\text { mass }(\mathrm{g})\end{array}$ & $\begin{array}{l}\text { Body water } \\
\text { content }(\mathrm{g})\end{array}$ & $\begin{array}{l}\text { Fat wet } \\
\text { mass }(\mathrm{mg})\end{array}$ \\
\hline$-1 \mathrm{~h}$ & $3 \pm 3$ & $1.38 \pm 0.045$ & $5.35 \pm 0.16$ & $441 \pm 29$ \\
$2 \mathrm{~h}$ & $1030 \pm 170 \dagger$ & $1.41 \pm 0.042$ & $5.05 \pm 0.14$ & $422 \pm 27$ \\
$6 \mathrm{~h}$ & $533 \pm 180 \dagger$ & $1.35 \pm 0.045$ & $5.33 \pm 0.16$ & $377 \pm 29$ \\
1 day & $611 \pm 200 \dagger$ & $1.31 \pm 0.045$ & $6.07 \pm 0.16^{*}$ & $431 \pm 27$ \\
2 days & $35 \pm 3 \dagger$ & $1.39 \pm 0.049$ & $5.49 \pm 0.17$ & $482 \pm 31$ \\
3 days & $8 \pm 5$ & $1.36 \pm 0.049$ & $5.56 \pm 0.17$ & $437 \pm 29$ \\
4 days & $0 \pm 0$ & $1.44 \pm 0.049$ & $5.44 \pm 0.17$ & $418 \pm 31$ \\
5 days & $0 \pm 0$ & $1.35 \pm 0.049$ & $5.51 \pm 0.17$ & $313 \pm 31^{*}$ \\
6 days & $0 \pm 0$ & $1.37 \pm 0.049$ & $5.60 \pm 0.17$ & $380 \pm 31$ \\
14 days & $0 \pm 0$ & $1.45 \pm 0.049$ & $5.60 \pm 0.17$ & $374 \pm 37$ \\
31 days & $0 \pm 0$ & $1.29 \pm 0.041$ & $5.04 \pm 0.14$ & $379 \pm 26^{*}$ \\
\hline
\end{tabular}

${ }^{*} \mathrm{P}<0.05, \dagger \mathrm{P}<0.0001$. Samples are identified by the time of food deprivation following a satiation feeding. MANOVA determined a significant overall Time effect (Wilks' Lambda: 11,54; $\mathrm{F}=5.98$, and Stomach Contents $(\mathrm{F}=11.07 ; \mathrm{P}<0.0001)$, Body Water Content $(\mathrm{F}=43.23 ; \mathrm{P}<0.001)$ and $\mathrm{Fat}$ Mass $(\mathrm{F}=3.35 ; \mathrm{P}=0.0008)$ significantly changed over time. Because body mass (wet and dry) and fat mass were correlated with original body mass, least square means \pm SEM are listed; for stomach contents means \pm SEM are listed. ${ }^{*}$ Samples that were significantly different from the prefeeding $(-1 \mathrm{~h})$ sample.
(A)
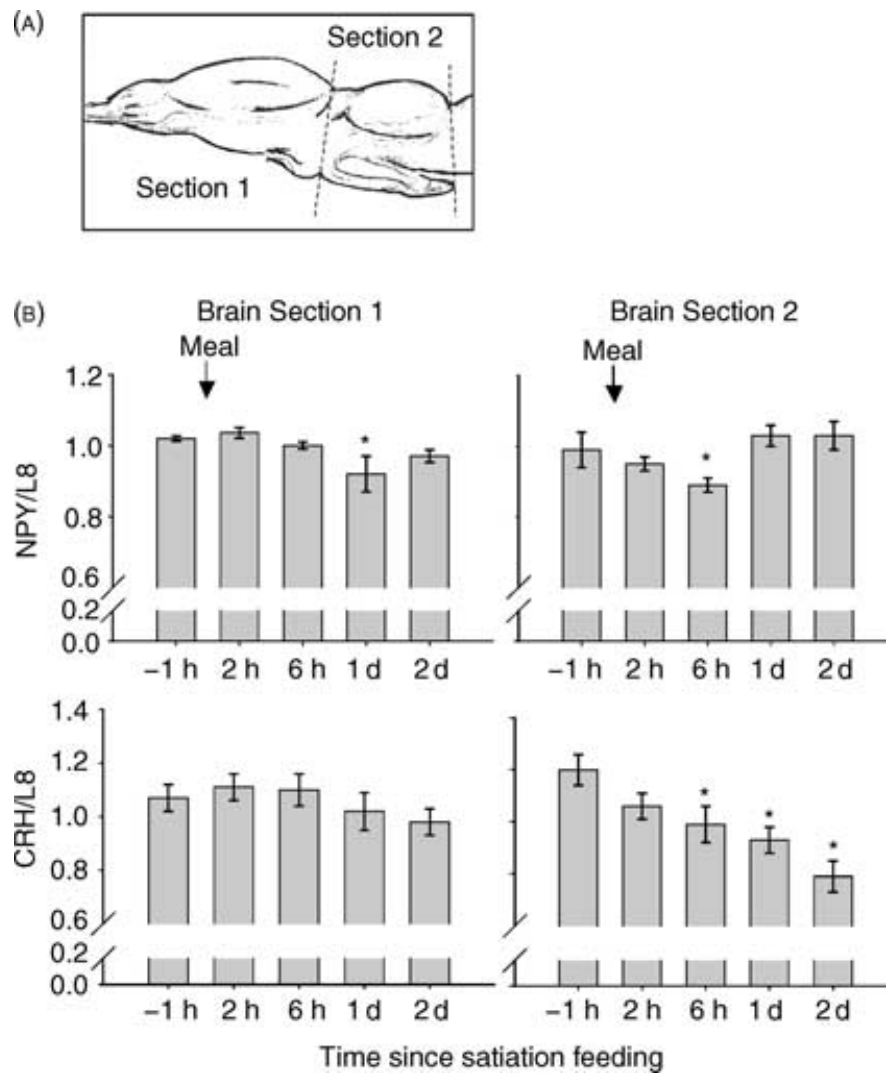

FIG. 3. Analysis of corticotropin-releasing factor (CRF) and neuropeptide $Y$ (NPY) mRNA content in the Xenopus laevis brain. (A) Illustration of a generalized amphibian brain and the location of sections dissected for semiquantitative multiplex reverse transcription-polymerase chain reaction analyses. (B) Fluctuation of CRF and NPY mRNA concentrations with feeding and food deprivation in $X$. laevis juveniles $(\mathrm{n}=3-5)$. Ribosomal protein $\mathrm{rpL} 8$ was used as a housekeeping gene to control for loading differences, and values represent the ratio in band intensity of CRF or NPY to rpL8. *Sample mean is significantly different $(\mathrm{P}<0.05)$ from the prefeeding group $(-1 \mathrm{~h})$. Significance determined by Dunnett-Hsu multiple comparisons tests on least-squares means for CRF mRNA, and Duncan's multiple comparisons tests on ratio means for NPY mRNA.

which included the preoptic area, did not change following food deprivation (compared to the prefeeding level) except at day 4 [ANOVA: $F(10,42)=2.16, P=0.039$ ] (Table 2). In brain Section 2, which included the mid-posterior hypothalamus, tectum, and pretectum, CRF mRNA expression declined immediately after feeding to a level significantly lower than that of the prefeeding group by $6 \mathrm{~h}$ after the meal [ANOVA: $\mathrm{F}(10,42)=3.33, \mathrm{P}=0.004$ ] (Fig. 3B). CRF mRNA expression in all subsequent food deprivation periods was significantly lower than in the prefeeding group (Table 2).

NPY mRNA expression in brain Section 1 significantly decreased by 1 day after the meal (Fig. 3B), but returned to prefeeding levels by 2 days of food deprivation [ANOVA: $\mathrm{F}(10,40)=2.09, \mathrm{P}=0.049]$. However, after 31 days of food deprivation, NPY mRNA expression was significantly lower than prefeeding levels (Table 2). In brain Section 2, NPY mRNA expression decreased by $6 \mathrm{~h}$ after feeding, but then returned to prefeeding levels after 1 day [ANOVA: $\mathrm{F}(10,39)=2.46, \mathrm{P}=0.020$ ) (Table 2, Fig. 3B). 
284 Neuroendocrine control of food intake in Xenopus laevis

TABLE 2. Changes in Neuropeptide Y (NPY) and CorticotropinReleasing Factor (CRF) mRNA Expression With Feeding and Food Deprivation in Xenopus laevis Juveniles $(\mathrm{n}=5-7)$, as Determined by Semiquantitative Multiplex Reverse Transcription-Polymerase Chain Reaction.

\begin{tabular}{llllll}
\hline & \multirow{2}{*}{ NPY mRNA } & & & \multicolumn{2}{l}{ CRF mRNA } \\
\cline { 2 - 3 } \cline { 5 - 6 } Time & Section 1 & Section 2 & & Section 1 & Section 2 \\
\hline -1 h & $1.02 \pm 0.008$ & $0.99 \pm 0.05$ & & $1.07 \pm 0.05$ & $1.20 \pm 0.06$ \\
2 $\mathrm{h}$ & $1.04 \pm 0.02$ & $0.95 \pm 0.02$ & & $1.11 \pm 0.05$ & $1.06 \pm 0.05$ \\
6 $\mathrm{h}$ & $1.00 \pm 0.01$ & $0.89 \pm 0.02^{*}$ & & $1.10 \pm 0.06$ & $0.99 \pm 0.07^{*}$ \\
1 day & $0.92 \pm 0.05^{*}$ & $1.03 \pm 0.03$ & & $1.02 \pm 0.07$ & $0.93 \pm 0.05^{*}$ \\
2 days & $0.97 \pm 0.02$ & $1.03 \pm 0.04$ & & $0.98 \pm 0.05$ & $0.79 \pm 0.06^{*}$ \\
3 days & $1.03 \pm 0.02$ & $0.99 \pm 0.04$ & & $1.05 \pm 0.06$ & $0.98 \pm 0.05^{*}$ \\
4 days & $1.03 \pm 0.04$ & $1.06 \pm 0.06$ & & $0.84 \pm 0.06^{*}$ & $1.01 \pm 0.07^{*}$ \\
5 days & $1.00 \pm 0.03$ & $0.99 \pm 0.04$ & & $1.04 \pm 0.07$ & $0.86 \pm 0.07^{*}$ \\
6 days & $1.02 \pm 0.04$ & $1.05 \pm 0.02$ & & $0.95 \pm 0.06$ & $0.96 \pm 0.06^{*}$ \\
14 days & $0.99 \pm 0.04$ & $1.08 \pm 0.03$ & & $0.94 \pm 0.06$ & $0.87 \pm 0.06^{*}$ \\
31 days & $0.90 \pm 0.04^{*}$ & $0.96 \pm 0.03$ & & $0.95 \pm 0.05$ & $0.96 \pm 0.07^{*}$ \\
\hline
\end{tabular}

Values for mRNA concentration are ratios of band intensities of CRF mRNA/ ribosomal protein L8 (housekeeping gene). Samples are identified by the time of food deprivation following a satiation feeding. ${ }^{*}$ Samples that were significantly different $(\mathrm{P}<0.05)$ from the prefeeding $(-1 \mathrm{~h})$ sample.

\section{Plasma corticosterone measurements}

There was a peak in plasma corticosterone concentration $6 \mathrm{~h}$ after the meal compared with the prefeeding level (Fig. 4A); however, the full model that analysed plasma corticosterone concentration over the 31-day period of food deprivation was not significant at $\alpha=0.05$ [ANOVA: $\mathrm{F}(9,39)=1.92 ; \mathrm{P}=0.08$ ]. To confirm the trend of a corticosterone peak at $6 \mathrm{~h}$, we conducted a separate experiment that replicated the prefeeding $(-6 \mathrm{~h}), 6-\mathrm{h}, 1$-day, 2-day and 14-day food deprivation treatments $(n=3)$. The frogs were entrained to feeding times in the same way as those in the first experiment. This experiment confirmed a significant increase in plasma corticosterone concentration $6 \mathrm{~h}$ after the meal compared to the prefeeding group (also see results from Daily Fluctuations in Plasma Corticosterone Experiment), with no further increases following food deprivation of 1,2 , or 14 days [ANOVA: $F(4,10)=$ 7.61; $\mathrm{P}=0.006$ ] (Fig. 4A, inset).

\section{Plasma glucose and IGFBPs}

Plasma glucose concentration increased 1 day after feeding and returned to prefeeding levels by two days after feeding [ANOVA: $\mathrm{F}(10,54)=2.60 ; \mathrm{P}=0.019$ ] (Fig. 4B). Plasma glucose concentration remained relatively constant at approximately $70 \mathrm{mg} / \mathrm{dl}$ through 31 days of food deprivation. We also measured plasma IGFBPs because plasma profiles of IGFBP-1 are known to vary with energy balance in other vertebrates (26-29). Western ligand blot analysis resolved two IGFBP bands in $X$. laevis plasma (approximately $35 \mathrm{kDa}$ and $25 \mathrm{kDa}$, respectively) (Fig. $5 \mathrm{~A}$ ). We did not attempt to determine the identities of these proteins in $X$. laevis. The 25-kDa IGFBP band (hereafter referred to as XBP25) was similar in size to mammalian and fish $\operatorname{IGFBP}-1(27,28)$, and increased with food deprivation as previously shown in other vertebrate groups $(28,29)$. Plasma xBP25 levels increased within $2 \mathrm{~h}$ after satiation feeding, peaked at 2 days after feeding, and remained significantly higher than the prefeeding levels through 6 days of food deprivation [ANOVA: $\mathrm{F}(10,54)=7.48 ; \mathrm{P}<0.0001$ ] (Fig. 5B). We detected no significant difference in the plasma levels of the $35-\mathrm{kDa}$ protein $(\mathrm{xBP} 35)$ with nutritional state.
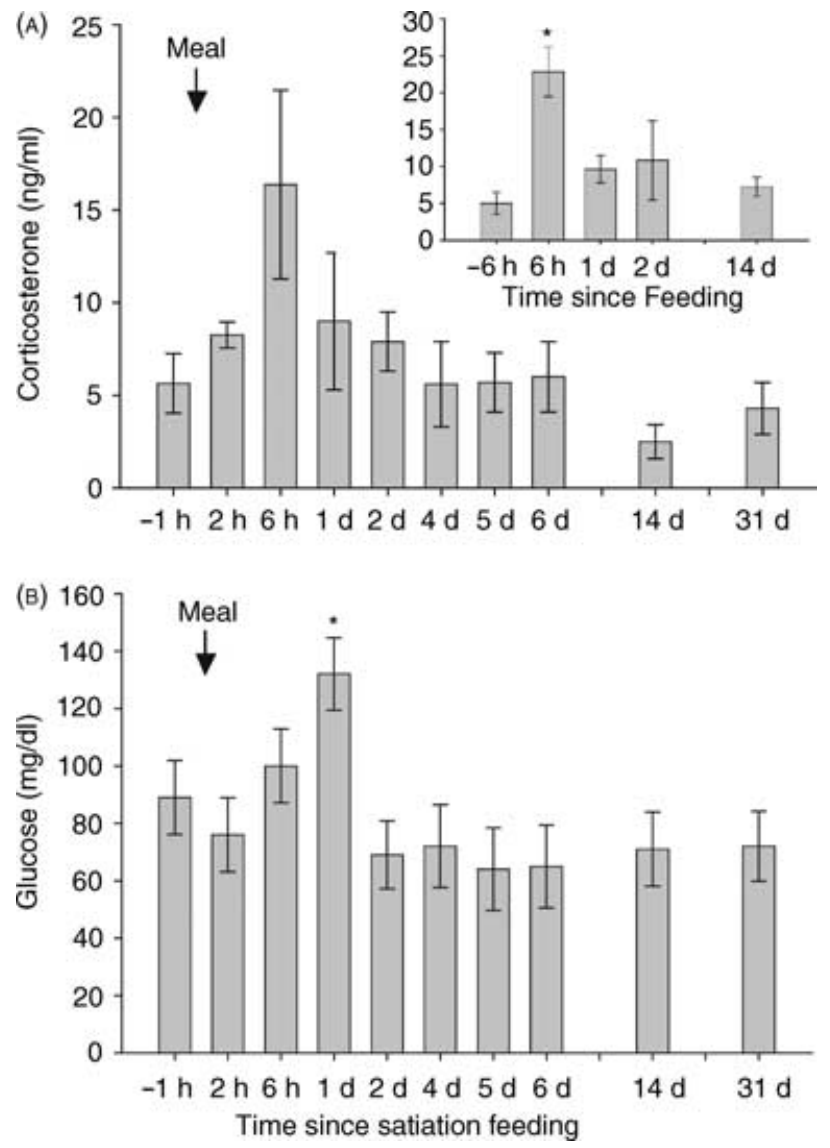

FIG. 4. Effects of feeding and food deprivation on (A) plasma corticosterone and (B) glucose concentrations. " Sample mean is significantly different $(\mathrm{P}<0.05)$ from prefeeding group $(-1 \mathrm{~h})$ as calculated by the Dunnett-Hsu multiple comparisons test on least-squares means adjusted for run differences.

\section{Measurement of daily fluctuations in plasma corticosterone and glucose concentration}

The purpose of this experiment was to determine whether daily plasma corticosterone fluctuations occur in frogs that had not been fed. In frogs entrained to a $13.00 \mathrm{~h}$ feeding time, plasma corticosterone concentrations were consistently low $(3.2-4.3 \mathrm{ng} / \mathrm{ml})$ in samples taken at $12.00 \mathrm{~h}$ over the course of the 3 days, but were elevated $(>8 \mathrm{ng} / \mathrm{ml})$ in the $18.00 \mathrm{~h}$ samples [ANOVA: $\mathrm{F}(5,20)=$ 3.32; $\mathrm{P}=0.02$ ] (Fig. 6A). As in the previous experiment, the postfeeding (day 1, 18.00 h) plasma corticosterone concentration was significantly greater than the prefeeding sample and all other $12.00 \mathrm{~h}$ samples. The $18.00 \mathrm{~h}$ samples taken on days without a meal were intermediate between the $12.00 \mathrm{~h}$ samples and the postfeeding sample. Plasma glucose concentration was significantly elevated in frogs sampled $24 \mathrm{~h}$ after the meal as in the previous experiment; all other samples were not significantly different from the day 1 prefeeding sample [ANOVA: $\mathrm{F}(5,24)=$ 3.86; $\mathrm{P}=0.01$ ] (Fig. 6B).

\section{Discussion}

The mammalian model of central nervous system control of energy balance proposes that food intake is regulated within 


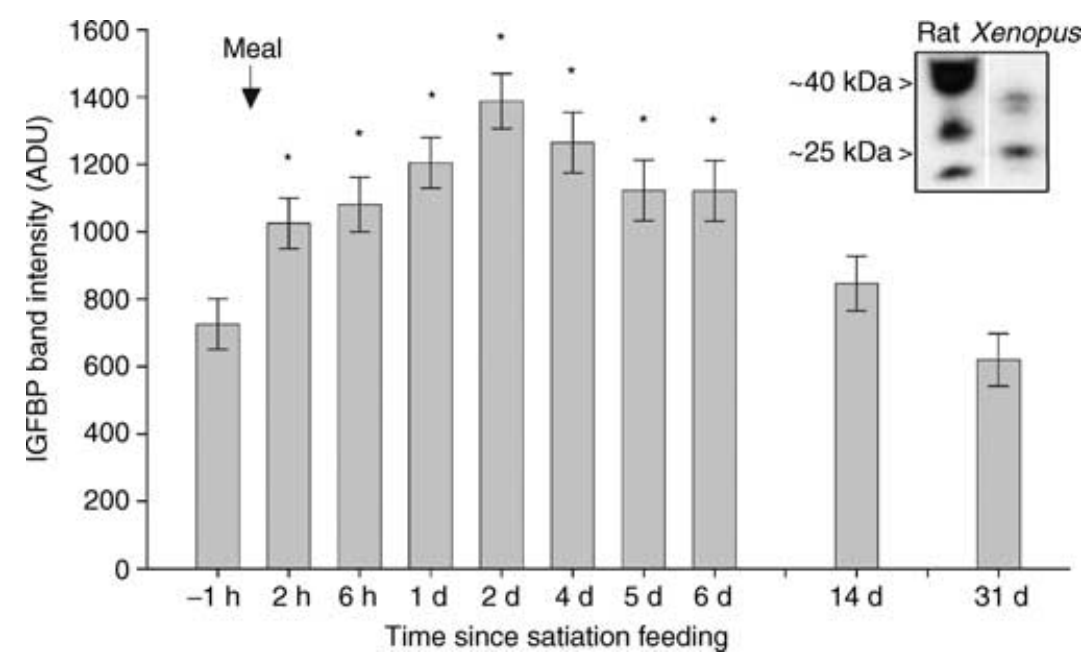

FIG. 5. Effects of satitation feeding and food deprivation on plasma insulin-like growth factor binding proteins (IGFBP). Inset: Representative bonding pattern of Xenopus laevis IGFBP resolved on a Western ligand blot showing two bands of approximately $35 \mathrm{kDa}$ and $25 \mathrm{kDa}$, respectively; rat plasma was used as a positive control in each blot. xBP25 levels $(n=4-5)$ of frogs subjected to varying lengths of food deprivation.

the hypothalamus by alternating actions of anorexigenic and orexigenic neuropeptides (7). In general, our data suggest that this model can also be applied to amphibians. In $X$. laevis, we found that i.c.v. injections of CRF suppressed food intake, whereas i.c.v. injections of NPY increased food intake as shown previously in mammals, birds, and fishes (2). Here, we present the first in vivo evidence for an orexigenic role for NPY in an amphibian, and our finding that CRF reduced meal size in $X$. laevis supports two previous studies in which CRF i.c.v. injections suppressed prey-catching behaviour in other species of frogs $(2$, 13). We also found that blocking CRF receptors increased food intake relative to uninjected controls (i.e. 'no-stress'), suggesting that basal (i.e. unstressed) CRF secretion modulates food intake in $X$. laevis.

Although many studies in mammals and fishes have shown that treatment with $\alpha$ helical CRF(9-41) blocks stress-induced suppression of food intake $(1,31)$, this is the first report of an increase in food intake resulting from the blockade of CRF receptors in the absence of stress. The effect of $\alpha$ helical CRF(9-41) in X. laevis is similar to that of CRF-BP overexpression in mice, which also increases food intake, presumably by reducing the free CRF concentration (8). Although the specific brain regions that mediate CRF effects on food intake is unknown in frogs, our data support the hypothesis that in the absence of stress, basal CRF secretion regulates food intake by eliciting a tonic, suppressive effect on appetite in amphibians.

The changes in hypothalamic CRF and NPY mRNA content with nutritional state in $X$. laevis also support the hypothesis that these neuropeptides have conserved appetite regulation functions across vertebrates. We found that NPY mRNA content was significantly lower in the midbrain region (section 2 ) by $6 \mathrm{~h}$ after a meal when appetite was suppressed, but returned to prefeeding levels by 1 day after the meal when appetite increases. Although we did not detect a significant increase with longer periods of food deprivation as seen in mammals (7), NPY mRNA levels remained significantly higher than the $6 \mathrm{~h}$ postmeal measure in almost all food deprivation treatments. The increase in NPY mRNA content with food deprivation was also shown by Northern blot analysis of
$X$. laevis midbrain sections sampled $6 \mathrm{~h}$ after a meal and after 14 days of food deprivation (E.J. Crespi and R.J. Denver, unpublished data). Given that we measured mRNA content in gross sections of the brain, it is possible that we did not detect increases in neuropeptide gene expression occurring within limited populations of cells in the tissue sample. Alternatively, NPY mRNA expression may not have increased beyond its $24 \mathrm{~h}$ postmeal levels because appetite does not increase with prolonged periods of food deprivation in X. laevis. For example, we found that frogs deprived of food for 31 days do not eat more in a single meal than frogs deprived of food for only 2 days (E.J. Crespi and R.J. Denver, unpublished data).

Although we did not observe an up-regulation of CRF mRNA during times of satiation ( $2 \mathrm{~h}$ and $6 \mathrm{~h}$ after feeding) as shown in mammals (32), we observed a significant decrease in CRF mRNA content with food deprivation when appetite is high, as also shown in mammals (33-35). Surprisingly, we saw the reduction in CRF mRNA content in the brain section containing the preoptic/optic tectum/mid-posterior hypothalamus (Section 2), but not in the section containing the preoptic area [homolog to the mammalian paraventricular nucleus (PVN); Section 1]. Studies in mammals have shown that CRF content is reduced in the PVN with food deprivation (33-35); however, most studies focus only on the PVN, even though other areas of the brain may be involved, because it is where CRF expression and secretion increases in response to physical and psychological stressors $(1,36)$. It is possible that we were unable to detect changes in CRF expression in the preoptic area because we measured mRNA in gross brain regions, and future studies using histochemistry would resolve this issue. Nevertheless, our results suggest that, in addition to the preoptic area, neurones in the mid-posterior hypothalamus, pretectum, and optic tectum may be important in CRF regulation of food intake and energy balance in $X$. laevis.

Although the effects of CRF and NPY on food intake appear to be similar between $X$. laevis and mammals, there were both similarities and differences in the plasma corticosterone profile with food intake and deprivation. First, as shown in mammalian studies $(3,4)$, acute increases in corticosterone significantly 

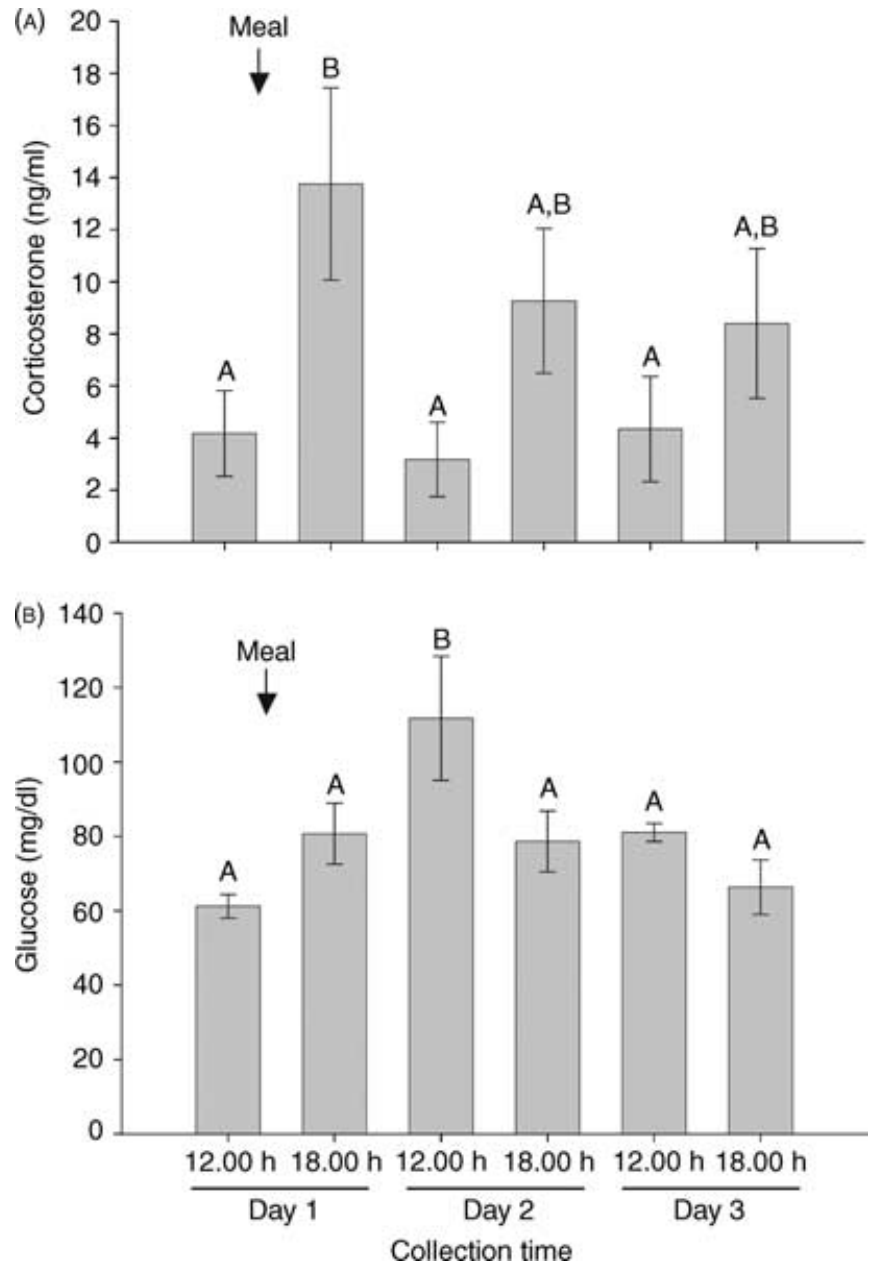

FIG. 6. (A) Plasma corticosterone and (B) glucose concentrations in Xenopus laevis juveniles entrained to a 48 -h feeding cycle $(\mathrm{n}=4-5)$ sampled at $12.00 \mathrm{~h}$ and $18.00 \mathrm{~h}$ over 3 days. A meal was given at $13.00 \mathrm{~h}$ on the first day, and no subsequent meals were given throughout the sampling period. Letters indicate statistically significant groupings as determined by Duncan's multiple comparison tests $(\mathrm{P}<0.05)$.

increased food intake in $X$. laevis juveniles, suggesting an orexigenic effect of corticosterone in frogs. We did not detect a negative effect of metyrapone on food intake in this study but, because appetite was extremely low in the control frogs, it was difficult to resolve significant decreases in food intake.

Second, $X$. laevis exhibited an increase in corticosterone $6 \mathrm{~h}$ after satiation feeding, suggesting that the hypothalamic-pituitaryinter-renal (HPI) axis was stimulated by food intake. Similar increases in plasma corticosterone have been measured several hours after a meal in adult X. laevis (37) and fishes (38-40). The timing of the postprandial glucose peak $(24 \mathrm{~h})$ is also similar between $X$. laevis and fishes. By contrast, rats and humans display a rapid, postprandial corticosterone 'pulse' that occurs within minutes after a meal, followed by an equally rapid pulse in plasma glucose that returns to baseline concentrations within hours $(35$, 41). The difference in timing of the postprandial corticosterone peak between amphibians/fish and mammals may represent differences in metabolic rate (i.e. ectothermic versus endothermic), habitat (aquatic versus terrestrial), feeding modes (carnivores versus omnivores/herbivores), or inherent phylogenetic differences.

We propose that the difference in timing of the corticosterone peak may also reflect functional differences of glucocorticoids among vertebrate groups. In mammals, the rapid increase in plasma corticosterone is thought to stimulate a rapid increase in gluconeogenesis and increased glucose transport following a meal (41). While corticosterone also stimulates gluconeogenesis in fish and amphibians $(37,40)$, we showed that the elevation of plasma concentrations after a meal is associated with osmoregulatory changes in $X$. laevis. We measured a significant increase in body water content $24 \mathrm{~h}$ after the meal, and observed that the intestines filled with fluid within hours after the meal (although we did not quantify this). Corticosterone has been shown to regulate intestinal ion uptake, water absorption and enzyme production in diverse vertebrate species including amphibians (42), although aldosterone also can serve this function (and has been shown to increase in response to feeding) (37). Most studies investigating the osmoregulatory role of corticosterone in amphibians and fishes have focused on dehydration or exposure to hyper- or hypoosmotic aquatic environments (42). However, it is possible that corticosterone may be playing an important osmoregulatory role in the digestive process that has yet to be described.

The increase in plasma corticosterone concentration after a meal in X. laevis has been previously interpreted as a circadian rhythm because concentrations peaked and returned to baseline concentrations within $24 \mathrm{~h}$ (37). Circadian rhythms in plasma corticosterone have been measured in other vertebrates, with increases in plasma corticosterone occurring just before the active phase when feeding typically takes place [fish (38-40); birds (4344); mammals (45)]. We found that when food is restricted from frogs that had been maintained on a regular feeding schedule, modest increases in plasma corticosterone continue at the same time of day as the usual postprandial corticosterone peak. Although we did not measure plasma corticosterone at a sufficient number of time points to fully describe a circadian rhythm, our data suggest that corticosterone secretion may have an endogenous rhythm that could be entrained by the timing of food intake.

Interestingly, neither plasma corticosterone concentration nor CRF mRNA content increased with periods of food deprivation up to 31 days in $X$. laevis. While plasma cortisol concentration also remains low with food deprivation in fishes (46), this result contrasts strikingly with the increase in plasma corticosterone observed after only hours of food deprivation in endothermic animals $(3,47,48)$. The increase in plasma corticosterone caused by food deprivation is thought to be a stress response that promotes increased appetite, foraging behaviour, and the mobilization of stored fuel in endotherms (48). The maintenance of relatively low plasma corticosterone concentrations during food deprivation in $X$. laevis may reflect the low metabolic rate characteristic of ectothermic animals. Even after 31 days of food deprivation, $X$. laevis maintained a positive energy balance as reflected by constant plasma glucose concentrations and body mass (wet or dry). Thus, the activation of the HPI axis and a compensatory increase in plasma corticosterone would not be expected. Frogs may have just reached a state of negative energy balance at the end of the 31-day food deprivation period, as fat mass, plasma xBP25 levels and NPY mRNA content began to decline. This pattern suggests a strategy of energy conservation in situations of low food availability in amphibians, as opposed to a 
strategy of increased foraging and mobilization of stored fuels exhibited by endothermic vertebrates, such as birds and rodents, that have much higher energy requirements for survival (48).

Finally, we documented the existence of at least two plasma IGFBPs in $X$. laevis. The molecular weight and plasma profiles following food intake and deprivation of xBP25 are similar to those of IGFBP-1 observed in other vertebrates. In mammals, IGFBP-1 production is stimulated by long-term glucose deprivation, and the protein is thought to sequester free IGFs in blood plasma and prevent their action in peripheral tissues (i.e. IGFBP-1 exerts a glucose counterregulatory role by neutralizing the hypoglycemic potential of free IGF-I) (26-27). IGFBP-1 is also secreted in times of stress and periods of prolonged food deprivation in fish, presumably to restrict the growth-promoting/hypoglycemic actions of free IGF-I and thus to allow for the conservation of energy resources $(27,28)$. In X. laevis juveniles, we showed a similar increase in plasma xBP25 with food restriction, but we do not yet know if this band corresponds to the $X$. laevis IGFBP-1.

In conclusion, our results show that, in $X$. laevis, exogenous NPY and corticosterone are orexigenic, and CRF is anorexigenic, as has been shown in other vertebrates. Furthermore, both NPY and CRF mRNA content varied with food intake in ways that were consistent with these effects on appetite. NPY mRNA content declined after a meal, when appetite was low, and increased when appetite was elevated. Conversely, CRH mRNA content remained low through prolonged periods of food deprivation when appetite was high. Plasma concentrations of corticosterone increased by $6 \mathrm{~h}$ after a meal, suggesting that food intake activates the HPI axis. This increase in plasma corticosterone concentration was associated with subsequent increases in plasma glucose and $\mathrm{xBP}$ $25 \mathrm{kDa}$ (presumptive $X$. laevis IGFBP-1), and body water content. However, during periods of short-term or long-term food deprivation, neither plasma corticosterone concentration nor CRF content increased. The corticosterone profiles associated with food intake and food deprivation are similar to those observed in fishes, but are strikingly different from those of endotherms. These differences likely reflect physiological, ecological or phylogenetic differences among vertebrates. Future comparative studies of the neuroendocrine controls of food intake in a diversity of animals with varying life histories are needed for a more thorough understanding of the evolution of the regulation of energy balance in vertebrates.

\section{Acknowledgements}

We would like to thank Dr Cunming Duan for providing radiolabelled $\left[{ }^{125}\right.$ I]human IGF-I for the IGFBP Western ligand blot assays. We thank Mary Stenzel-Poore for providing the $X$. laevis genomic CRF clones. This work was funded by NSF grants IBN 9974672 and IBN 0235401 to R.J.D. E.J.C. was supported by a NIH training grant (T32-HD07048) administered by the Reproductive Sciences Program at the University of Michigan.

\section{Accepted 26 January 2004}

\section{References}

1 Heinrichs SC, Richard D. The role of corticotropin-releasing factor and urocortin in the modulation of ingestive behavior. Neuropeptides 1999; 33: $350-359$.

2 Carr JA, Brown CL, Roshi M, Venkatesan S. Neuropeptides and amphibian prey-catching behavior. Comp Biochem Physiol 2002; B 132: $151-162$.

3 Dallman MF, Akana SF, Strack AM, Hanson ES, Sebastian RJ. The neural network that regulates energy balance is responsive to glucocorticoids and insulin and also regulates HPA axis responsivity at a site proximal to CRF neurons. Ann NY Acad Sci 1995; 771: 730-742.

4 Tataranni PA, Larson DE, Snitker S, Young JB, Flatt JP, Ravussin E. Effects of glucocorticoids on energy metabolism and food intake in humans. Am J Physiol 1996; 271: E317-E325.

5 Gregory TR, Wood CM. The effects of chronic plasma cortisol elevation on the feeding behavior, growth, competitive ability, and swimming performance of juvenile rainbow trout. Physiol Biochem Zool 1999; 72: $286-295$.

6 Sapolsky RM, Romer LM, Munck AU. How do glucocorticoids influence stress responses? Integrating permissive, suppressive, stimulatory, and preparative actions. Endocr Rev 2000; 21: 55-89.

7 Schwartz MW, Woods SC, Prote D Jr, Seeley RJ, Baskin DG. Central nervous system control of food intake. Nature 2000; 404: 661-671.

8 Karolyi IJ, Burrows HL, Ramesh TM. Altered anxiety and weight gain in corticotropin-releasing hormone-binding protein-deficient mice. Proc Natl Acad Sci USA 1999; 96: 11595-11600.

9 Stanley BG, Lanthier D, Chin AS, Leibowitz SF. Suppression of neuropeptide-Y-elicited eating by adrenalectomy or hypothysectomy-reversal with corticosterone. Brain Res 1989; 501: 32-36.

10 Yao M, Westphal N, Denver RJ. Acute stress-induced elevation in corticotropin-releasing hormone expression in Xenopus laevis. Integr Comp Biol 2002; 42: 1341.

11 Tuinhof R, Gonzalez A, Smeets WJAJ, Roubos EW. Neuropeptide Y in the developing and adult brain of the South African clawed toad Xenopus laevis. J Chem Neuroanat 1994; 7: 271-283.

12 Denver RJ, Boorse GC, Glennemeier KA. Endocrinology of complex life cycles: amphibians. In: Pfaff D, Arnold A, Etgen A, Fahrbach S, Moss R, Rubin R, eds. Hormones, Brain and Behavior, vol. 2. San Diego: Academic Press, 2002: 469-513.

13 Corpas I, Gancedo B, Alonso-Gomez AL, Delgado MJ, Alondo-Bedate M. Food intake inhibition and metamorphic stimulation by sheep corticotropin-releasing hormone (CRF) administration in Rana perezi. Belg $J$ Zool 1991; 121: 132-133.

14 Glennemeier KA, Denver RJ. Role of corticoids in mediating the response of Rana pipiens tadpoles to intraspecific competition. J Exp Zool 2002; 292: $32-40$.

15 Galas L, Tonon MC, Beaujean D, Fredriksson R, Larhammar D, Lihrmann I, Jegou S, Fournier A, Chartrel N, Vaudry H. Neuropeptide Y inhibits spontaneous alpha-melanocyte-stimulating hormone (alphaMSH) release via a Y-5 receptor and suppresses thyrotropin-releasing hormone-induced alpha-MSH secretion via a Y-1 receptor in frog melanotrope cells. Endocrinology 2002; 143: 1686-1694.

16 Dautenberg FM, Dietrich K, Palchaudhuri MR, Spiess J. Identification of two corticotropin-releasing factor receptors from Xenopus laevis with high ligand selectivity: unusual pharmacology of the type 1 receptor. J Neurochem 1997; 69: 1640-1649.

17 Valverde RA, Seasholtz AF, Cortright DN, Denver RJ. Biochemical characterization and expression of the Xenopus laevis corticotropinreleasing hormone binding protein. Mol Cell Endocrinol 2001; 173: $29-40$.

18 Chartrel N, Conlon M, Danger JM, Fournier A, Tonon MC, Vaudry H. Characterization of melanotropin release-inhibiting factor (melanostatin) from frog brain: homology with human neuropeptide Y. Proc Natl Acad Sci USA 1991; 88: 3862-3866.

19 Licht P, McCreery BR, Barns R, Pang R. Seasonal and stress related changes in plasma gonadotropins, sex steroids, and corticosterone in the bullfrog, Rana catesbeiana. General Comp Endocrinol 1983; 50: 124-145.

20 Lowry CA, Moore FL. Corticotropin-releasing factor (CRF) antagonist suppresses stress-induced locomotor activity in an amphibian. Horm Behav 1991; 25: 84-96.

21 Hayes $\mathrm{T}, \mathrm{Wu} \mathrm{TH}$. Interdependence of corticosterone and thyroid hormones in toad larvae (Bufo boreas). II. Regulation of corticosterone and thyroid hormones. J Exp Zool 1995; 271: 103-111.

22 Stenzel-Poore MP, Heldwein KA, Stenzel P, Lee S, Vale WW. Characterization of the genomic corticotropin-releasing factor (CRF) gene from Xenopus laevis: two members of the CRF family exist in amphibians. Mol Endocrinol 1992; 6: 1716-1724.

23 Shi Y-B, Liang VCT. Cloning and characterization of the ribosomalprotein L8 gene from Xenopus laevis. Biochem Biophys Acta 1994; 1217: $227-228$. 
288 Neuroendocrine control of food intake in Xenopus laevis

24 Pernas-Alonso R, Morelli F, di Porzio U, Perrone-Capano C. Multiplex semi-quantitative reverse transcriptase-polymerase chain reaction of low abundance neuronal mRNAs. Brain Res Protoc 1999; 4: 395-406.

25 Raabo E, Terkildsen TC. On the enzymatic determination of blood glucose. Scand J Clin Laboratory Invest 1960; 12: 402.

26 Denver RJ, Nicoll CS. Pancreatic hormones differentially regulate insulin-like growth factor (IGF)-I and IGF-binding protein production by primary rat hepatocytes. J Endocrinol 1994; 142: 299-310.

27 Lewitt MS. Role of insulin-like growth factors in the endocrine control of glucose homeostasis. Diabetes Res Clin Pract 1994; 23: 3-15.

28 Kelley KM, Schmidt KE, Berg L, Sak K, Galima MM, Gillespie C, Balogh L, Hawayek A, Reyes JA, Jamison M. Comparative endocrinology of the insulin-like growth factor-binding protein. J Endocrinol 2002; 175: 3-18.

29 Maures TJ, Duan CM. Structure, developmental expression, and physiological regulation of zebrafish IGF binding protein-1. Endocrinology 2002; 143: 2722-2731.

30 Hossenlopp P, Seruin D, Segovia-Quinson B, Hardouin S, Binouox M. Analysis of serum insulin-like growth factor binding proteins using Western blotting: use of the method for titration of the binding proteins and competitive binding studies. Anal Biochem 1986; 154: 138-143.

31 Bernier NJ, Peter RE. Appetite-suppressing effects of urotensin I and corticotropin-releasing hormone in goldfish (Carassius auratus) Neuroendocrinology 2001; 73: 248-260.

32 Seeley RJ, Matson CA, Chavez M, Woods SC, Dallman MF, Schwartz MW. Behavioral, endocrine, and hypothalamic responses to involuntary overfeeding. Am J Physiol 1996; 271: R819-R823.

33 Hwang BH, Guntz JM. Downregulation of corticotropin-releasing factor mRNA, but not vasopressin mRNA in the paraventricular hypothalamic nucleus of rats following nutritional stress. Brain Res Bull 1997; 43: 509-514.

34 Timofeeva E, Richard D. Functional activation of CRF neurons and expression of the genes encoding $\mathrm{CRF}$ and its receptors in food-deprived lean (Fa/?) and obese (fa/fa) Zucker rats. Neuroendocrinology 1997; 66: 327-340.

35 Dallman MF, Akana SF, Bhatnagar S, Bell ME, Choi S, Chu A, Horsely C, Levin N, Meijer O, Soriano L, Strack AM. Starvation: early signals, sensors, and sequelae. Endocrinology 1999; 140: 4015-4022.
36 Cone RD. The corticotropin-releasing hormone system and feeding behavior-A complex web begins to unravel. Endocrinology 2000; 141: 2713-2714.

37 Thurmond W, Kloas W, Hanke W. Circadian rhythm of interrenal activity in Xenopus laevis. Gen Comp Endocrinol 1986; 61: 260-271.

38 Boujard T, Leatherland JF. Circadian rhythms and feeding time in fishes. Environ Biol Fishes 1992; 35: 109-131.

39 Holloway AC, Reddy PK, Sheridan MA, Leatherland JF. Diurnal rhythms of plasma growth hormone, somatostatin, thyroid hormone, cortisol, and glucose concentrations in rainbow trout, Oncorhynchus mykiss, during progressive food deprivation. Biol Rhythm Res 1994; 25: 415-432.

40 Reddy PK, Leatherland JF. Does the time of feeding affect the diurnal rhythms of plasma hormone and glucose concentration and hepatic glycogen content in rainbow trout? Fish Physiol Biochem 1994; 13: $133-140$.

41 Van Cauter E, Shapiro ET, Tillil H, Polonsky K. Circadian modulation of glucose and insulin responses to meals: relationship to cortisol rhythm. Am J Physiol 1992; 92: E467-E475.

42 Collie NL, Hirano T. Mechanisms of hormone actions on intestinal transport. In: Pang PKT, Schreibman MP, eds. Vertebrate Endocrinology Fundamentals and Biomedical Implications, vol. 2. New York: Academic Press, 1987: 239-270.

43 Ramenofsky M, Savard R, Greenwood MRC. Seasonal and diel transitions in physiology and behavior in a migratory dark-eyed junco. Comp Biochem Physiol A Mol Integr Physiol 1999; 122: 385-397.

44 Breuner CW, Wingfield JC, Romero LM. Diel rhythms of basal stressinduced corticosterone in a wild, seasonal vertebrate, Gambel's whitecrowned sparrow. J Exp Zool 1999; 284: 334-342.

45 Aschoff J. Circadian timing. Ann NY Acad Sci 1984; 423: 442-468.

46 MacKenzie DS, VanPutte CM, Leiner KA. Nutrient regulation of endocrine function in fish. Aquaculture 1998; 161: 3-25.

47 Wingfield JC, Ramenofsky M. Corticosterone and facultative dispersal in response to unpredictable events. Ardea 1997; 85: 155-166.

48 Romero LM, Remage-Healey L. Daily and seasonal variation in response to stress in captive starlings (Sturnus vulgaris): corticosterone. Gen Comp Endocrinol 2000; 119: 52-59. 